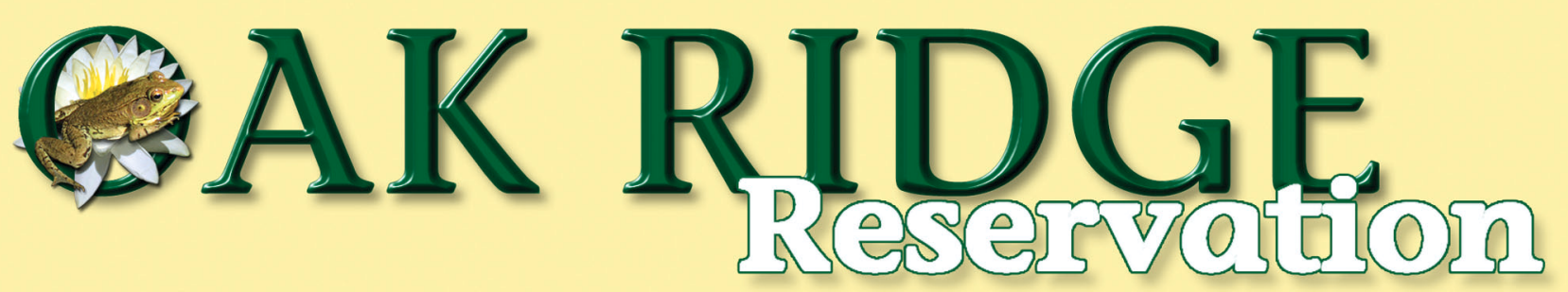

Annual Site Environmental Report Summary

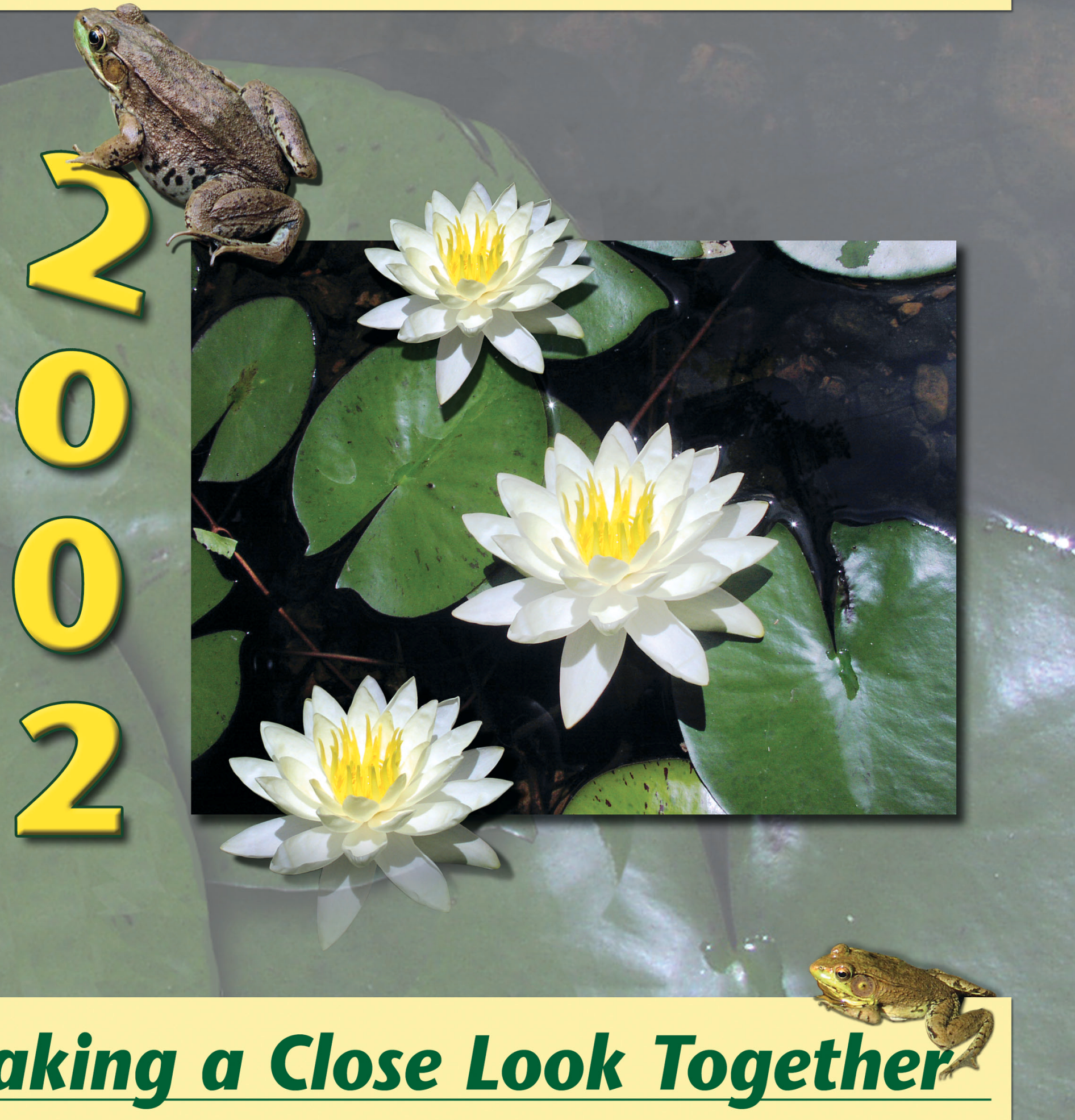




\section{Message from the Students}

\section{Dear DOE Stakeholder:}

We're the 2003 Applied Communications Class at Karns High School. We wrote down our thoughts on what we wanted to tell you about the Oak Ridge Reservation and about working on this document for the Department of Energy. At the beginning of this project we didn't know much at all about the Oak Ridge Reservation and even thought the Department of Energy produced energy in Oak Ridge, and that bombs were kept at the facilities. We had the opportunity to tour each facility, read documents and see videos about the history, learn about the research going on, and talk to scientists about environmental monitoring, the pollution that comes from the site, and all the cleanup work.

We learned so much it's hard to summarize, and we wish you could have been with us working on this project so you'd get a better idea and respect for the work being done there. Activities on the Oak Ridge Reservation include all kinds of research including product development, medicine, making new materials, nuclear applications, super computer development, and many things that will help this nation in many ways. Parts are made for nuclear weapons, and assistance is provided to other nations to help dismantle their old bombs. It surprised us to see that they spend millions of dollars each year to monitor the environment, and we learned all the ways that the environment is protected and cleaned up.

We tried to write this summary in a way that will hopefully let you better understand how much effort goes into monitoring and protecting the environment and the public. Despite all the myths, the Oak Ridge Reservation is valuable and is helping the environment in many ways. Oak Ridge is not about the bomb, it's about the community and cleaning the environment and protecting it, and it's a safe place. We looked closely at the level of radiation and other pollutants, and now understand what the levels mean. We see that the facilities comply with environmental laws and regulations and that pollutants released from the reservation are very rarely above what the regulations allow.

The theme for this summary is "Taking a Close Look." Hopefully we've helped you better understand the Oak Ridge Reservation and the kind of neighbor it is. Thanks go to our trusty teacher, Jennifer Webster, for her help and for letting us do this project, Joan Hughes from Oak Ridge National Laboratory, and Dr. Tim Joseph from the Department of Energy for working with us so closely, and showing us how creative we really can be. And thank you, Department of Energy stakeholders, for wanting us to do this document. We hope we've been able to help you better understand and appreciate the Oak Ridge Reservation. We sure do.

Have a great year.

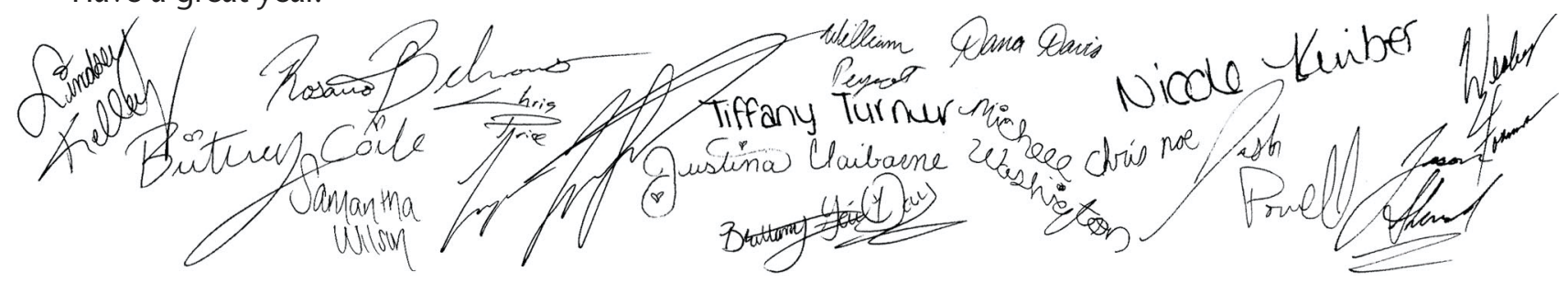

\section{About the cover:}

"Taking a Close Look Together" A small frog, a water lily, and the water in the pond tell us so much if we look closely. Together we must never stop looking at what is being shown to us by the environment, for it calls out to us as clearly as the frog's nightly ballad, constantly telling us how it's doing and what it may need. As the Department of Energy, industry, stakeholders, and the public, we must look, listen, understand, and respond. Always. - Timothy Joseph

Cover photography: Katelyn R. Oliver, Karns High School student artist

Layout and design: Gail S. Sweeden, Communications and Community Outreach, UT-Battelle

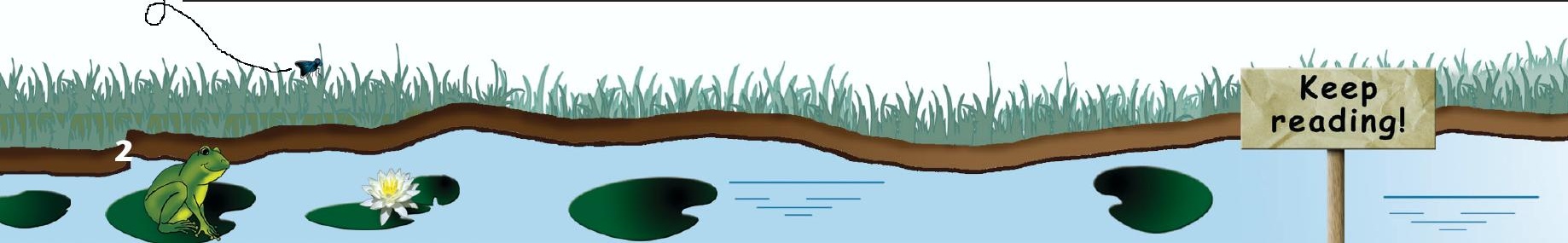




\section{Credits}

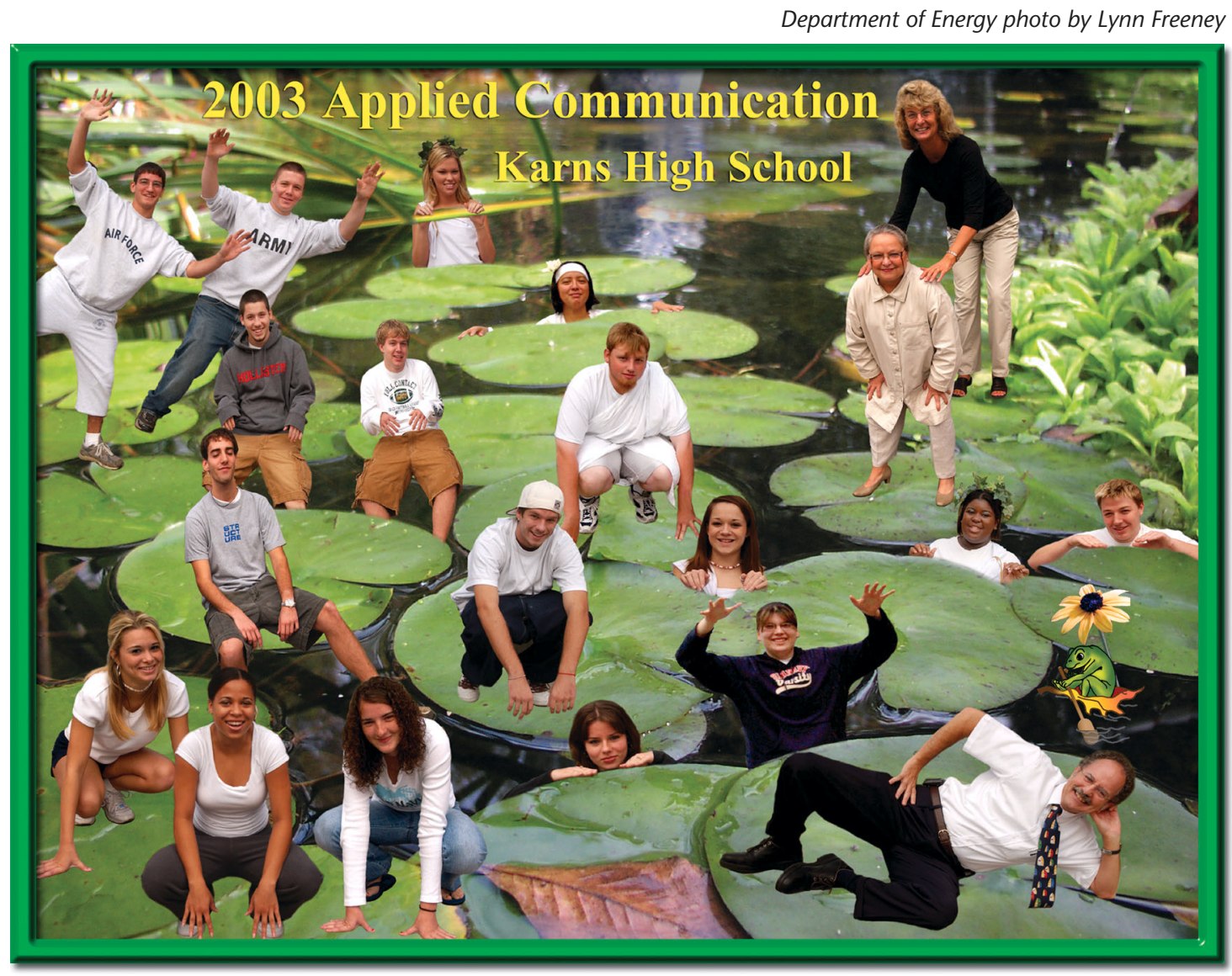

Front row left to right: Justina Claiborne, Nicole Kimber, Britney Coile, Dana Davis Lindsey Kelley, and Timothy Joseph Second row left to right: Jason Sherrod, Josh Powell, Tiffany turner, Michelle Washington, and Chris Noe Third row left to right: Logan Lunsford, Wes Forman, Chris Price, Jennifer Webster, and Joan Hughes Fourth row left to right: Will Peyrot, Tim Johnson, Samantha Wilson, and Rosario Belmares

Oak Ridge Reservation Annual Site Environmental Report Summary for 2001

on the World Wide Web: http:/www.ornl.gov/aser

\section{Contributors}

Fall 2002 Applied Communications Class and Spring 2002 Art Class Students Karns High School Jennifer C. Webster, Instructor and English Department Chairperson Karns High School

Joan Hughes, Project Director Oak Ridge National Laboratory
Andrea Haury and Bill Shinn

Art Teachers

Karns High School

Timothy W. Joseph, Ph.D., Project Manager

Department of Energy

Oak Ridge Operations Office

Gail Sweeden, Graphics and frog artwork, Creative Media Oak Ridge National Laboratory

Date published: December 2003

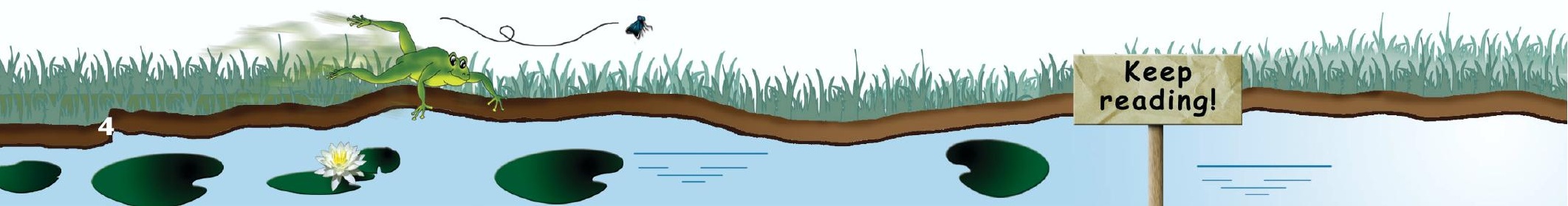




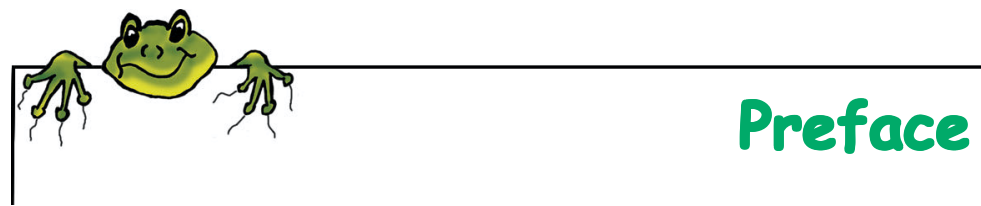

\section{Annual Site Environmental Report Summary-2002}

The "State-of-the-Environment" on and around the Oak Ridge Reservation is a mission of highest importance to the Department of Energy and our contractors. In order to be fully aware of the consequences of our operations and cleanup, an annual multimillion-dollar monitoring and surveillance program collects and analyzes tens of thousands of samples from air, surface and groundwater, soil, mud, plants, and animals.

A mission of equal importance is to provide our stakeholders a complete understanding of this program. To do this we publish a detailed Annual Site Environmental Report and this summary document. The raw data is published separately in the Data Volume. All three documents can be found on the web, along with past documents, at http://www.ornl.gov/aser.

Though I work on numerous technical documents throughout the year, no document is more important to me than the Annual Site Environmental Report and its Summary because:

1. they represent the efforts of many dedicated environmental scientists who carry out this extensive program, and who work hard to protect and enhance the environment;

2. they set out the programs in great detail to our legislatures, stakeholders, and the public; and

3. the Summary is directed to the public with the hope that the information is understandable and of value in gaining an accurate picture of the Oak Ridge Reservation as a neighbor.

I thank the Karns High School students and their teacher for accepting my challenge in writing this Annual Site Environmental Report Summary, for thinking out of the box, for doing such a fine job, and for all the artwork and photographs (the morning coffee in the classroom was greatly appreciated, leaks and all). They were an especially enjoyable class to work with, and I hope you, our stakeholders and the public, find their efforts of value.

As the Annual Site Environmental Report project manager it is my ardent hope you find this summary useful and easy to read. I am always interested in stakeholder feedback on how I can improve the report and its summary document, for they are written for you. I invite your comments, and can be reached by phone at 865-576-1582, or by email at: josepht@oro.doe.gov. Additional printed reports are available at the Department of Energy Information Center, or by calling 574-6649.

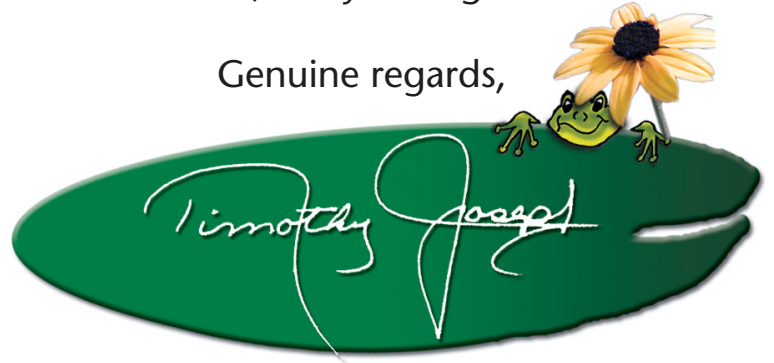

Timothy Joseph, Ph.D.

Senior Scientist

US. Department of Energy

Oak Ridge Operations

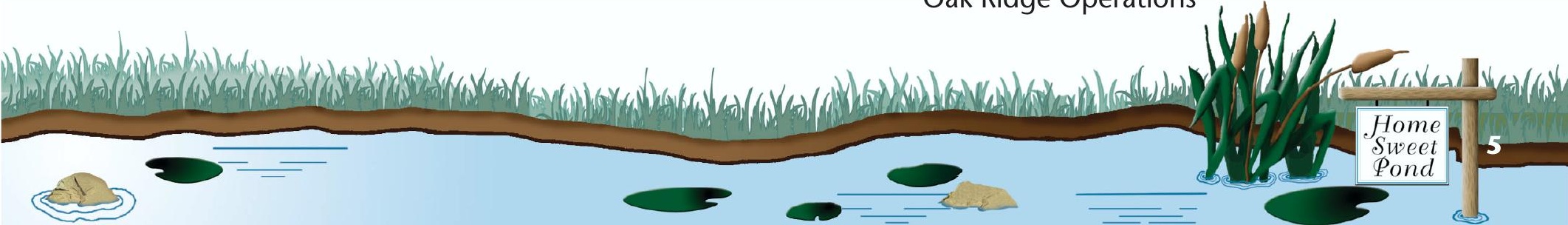




\section{Oak Ridge Reservation History}

The history of the Oak Ridge Reservation is very important to the nation. No matter how much is understood about it, there will probably remain some misunderstanding about the historical and present activities at the three Oak Ridge sites. We hope that this section provides a better understanding.

On December 7, 1941, the Japanese attacked Pearl Harbor. In 1942, with the world at war, the United States government purchased a rural area in East Tennessee to build secret plants for the war effort. The community, originally called Clinton Engineer Works, later to be named Oak Ridge, reached a population of more that 75,000 by the end of World War II. Only when the war ended was the role of this secret city revealed. Oak Ridge had been hurriedly constructed as part of the Manhattan Project, a secret program that pre-dated the United States' involvement in the war, to develop an atomic

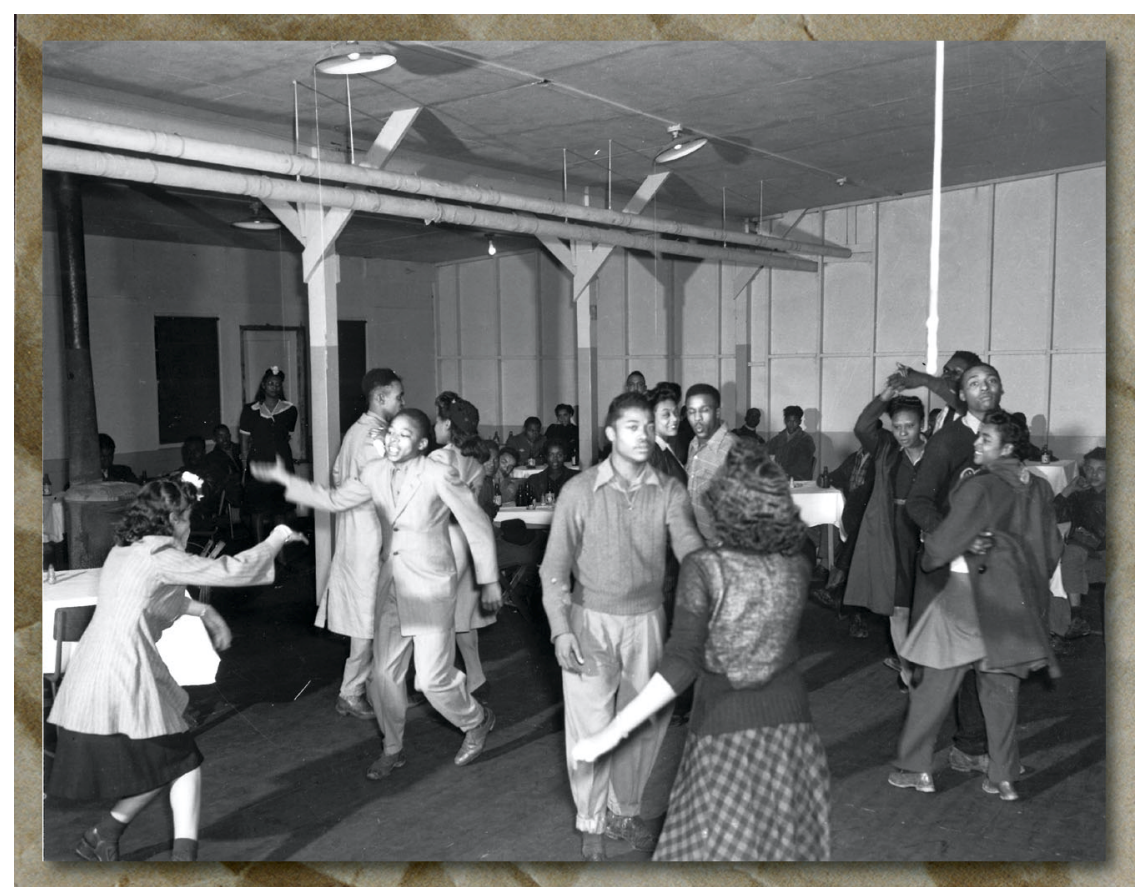

Saturday night fever, 1940s bomb, a powerful explosive nuclear weapon. The first major challenge faced in the Manhattan Project was the ability to find an acceptable and plentiful source of fuel for the bombs. At Oak Ridge techniques were devised to produce and purify the large quantities of fissionable uranium and plutonium that would be needed to construct the atomic bomb.

Massive research and production efforts were parceled out around the country. Teams of scientists and engineers undertook secret tasks at several closely guarded sites in addition to the Oak Ridge site including a remote mesa at Los Alamos, New Mexico; the experimental cyclotron and labs of the University of California; and the stark, remote valley of the upper Columbia River at Hanford, Washington.

\section{Why Oak Ridge?}

The Oak Ridge site was located along the Clinch River twenty miles west of Knoxville, Tennessee. The area was chosen for its temperate climate, surrounding mountains and isolating ridges, availability of a labor pool from the nearby city of Knoxville, an abundant source of water from the Clinch River, nearby highways and railroads, and access to the Tennessee Valley Authority's abundant electrical power. The site was also chosen because the army would not need to relocate as many people from this area as from other candidate locations.

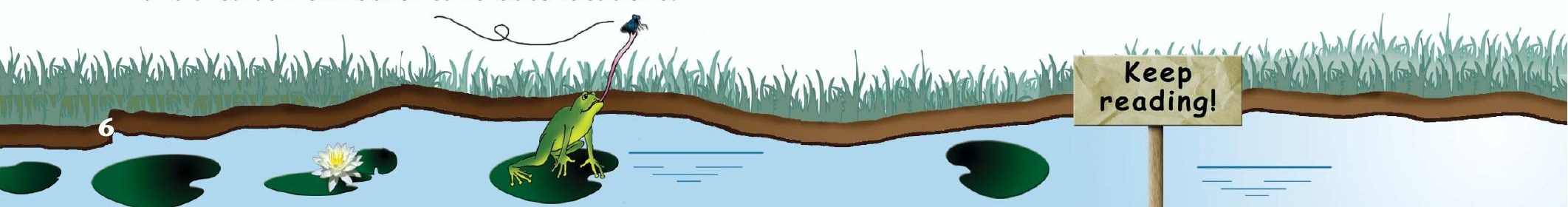




\section{Construction}

Construction began on Oak Ridge's three facilities in 1943. Built in record time under a cloak of great secrecy during World War II, Oak Ridge came into being as a major site in the Manhattan Project. Each plant was given a code name to disguise its operation. These code names - Y-12, K-25, and $\mathrm{X}-10$ —are still frequently used today to identify the three sites. The three plants were located in different valleys within a tightly controlled security area.

\section{$\mathrm{x}-10$}

The X-10 Plant was a pilot project. It consisted of the first full-scale nuclear reactor and

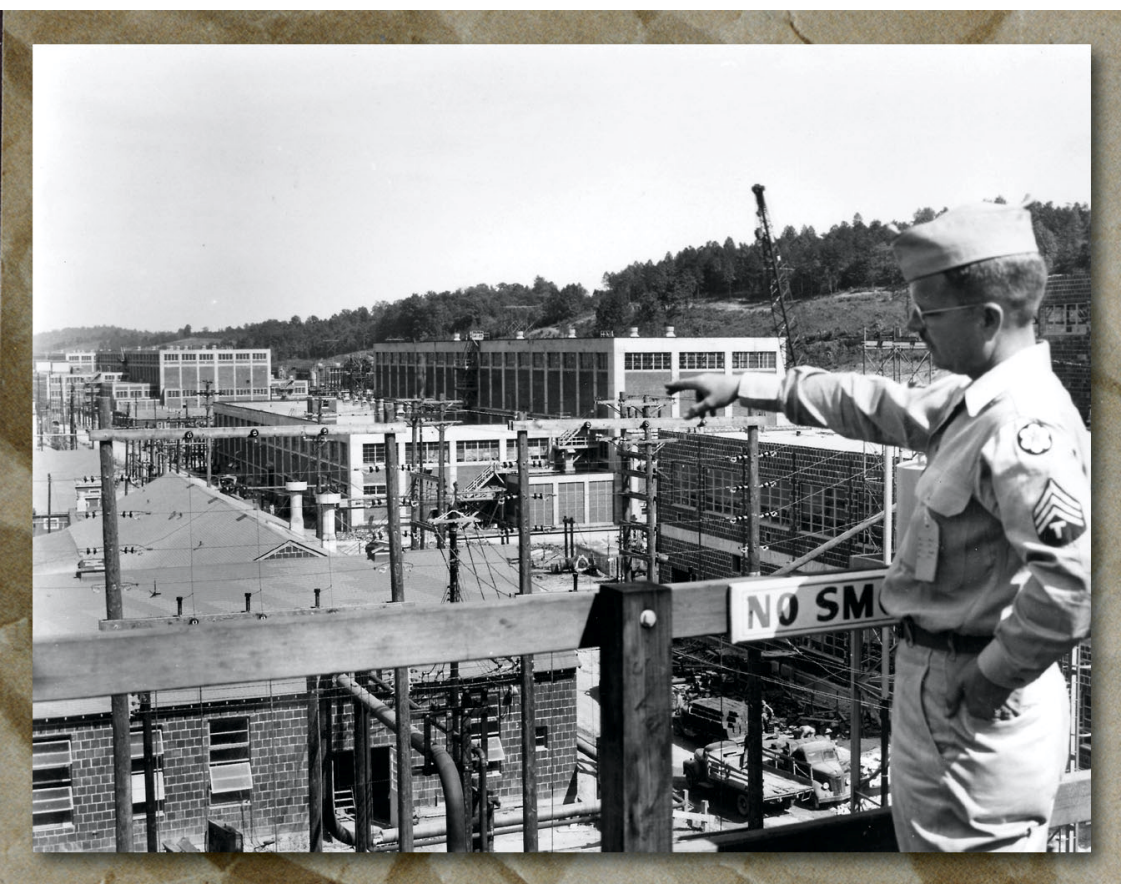

Y-12 construction during the 1940s support buildings for the production and chemical separation of plutonium. The X-10 Graphite Reactor was designed and built in ten months. The facility went into operation on November 4, 1943, and was decommissioned in 1963. The purpose was to create plutonium-239, a new element. The facility used chemical separation through a technique called the bismuth phosphate process. The process was so successful that the laboratory in Los Alamos received its first samples of the new element in the spring of 1944. After being decommissioned in 1963, the X10 Graphite Reactor became a national landmark, and public tours are given Monday through Friday 9 a.m. through 5 p.m.

\section{Y -12}

The Y-12 Electromagnetic Separation Plant was designed to produce enough enriched uranium to make fissionable material for an atomic bomb. It used large electromagnets for uranium separation in units called calutrons. All stops were pulled out to ensure the successful completion of Y-12's war mission. Over 13,500 tons of silver valued then at more than $\$ 300$ million - were loaned from the United States mint for use in the electromagnets at the Y-12 plant when copper was in short supply. Production began in November of 1943. In 1945, Y-12's construction was finished and the plant was

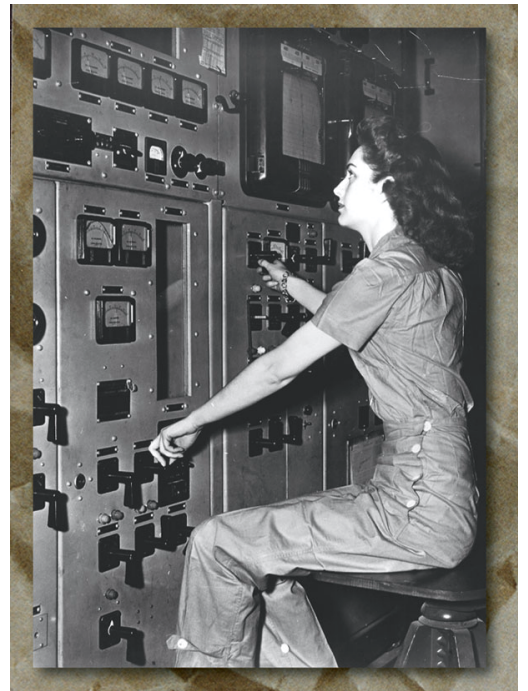

Helping the war effort at its peak with more than 22,000 workers. When gaseous diffusion became the accepted uranium enrichment process in 1946, Y-12's magnetic separators were taken out of commission. Y-12 is currently operated by BWXT. The plant stretches over 811 acres with more than 600 buildings. The primary missions of Y-12 now are: producing, refurbishing, and dismantling nuclear weapons components; safeguarding special nuclear material; providing the United States Navy with nuclear material for safe, military effective nuclear propulsion systems; and providing support for other national security needs as required. 


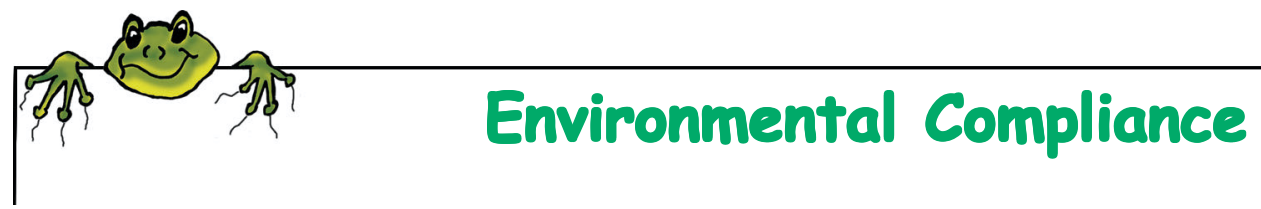

\begin{abstract}
In this section we have tried to help you understand the environmental laws and regulations that affect activities on the Oak Ridge Reservation, and describe compliance status with these requirements for 2002.
\end{abstract}

Activities on the Oak Ridge Reservation that generate hazardous wastes and deal with the cleanup of waste from past work are subject to federal, state, and local laws that are intended to protect the environment and public health. These laws limit or prohibit the emission of toxic substances into the air, water, and the ground, and include requirements for plans to prevent accidents, spills, and unplanned releases. Environmental laws also call for programs to monitor measure, document, and report on compliance to regulatory agencies and the public.

The United States Environmental Protection Agency and the Tennessee Department of Environment and Conservation are the primary regulators of Oak Ridge Reservation activities. These agencies issue permits, review compliance reports, participate in joint monitoring programs, inspect facilities and operations, and oversee compliance with applicable regulations. The Department of Environment and Conservation's Department of Energy Oversight Division is located in Oak Ridge to assure the public that their safety, health, and environment are protected as activities on the Oak Ridge Reservation are carried out.

\title{
2002 Compliance Status
}

- Each site achieved a National Pollutant Discharge Elimination System permit compliance rate greater than $99.9 \%$.

- All three Oak Ridge Reservation facilities operated in compliance with the Tennessee regulatory dose limits for Hazardous Air Pollutants for Radionuclides, and met all emission and test procedures.

- There were no releases by any of the facilities of reportable quantities of hazardous chemicals or asbestos. Releases are required to be reported under the Comprehensive Environmental Response, Compensation and Liability Act.

Note: Several private businesses operate under leasing arrangements at the East Tennessee Technology Park under the DOE Reindustrialization Program. Lessees are accountable for complying with all applicable standards and regulations and for obtaining permits and licenses with local, state, and federal agencies as appropriate.

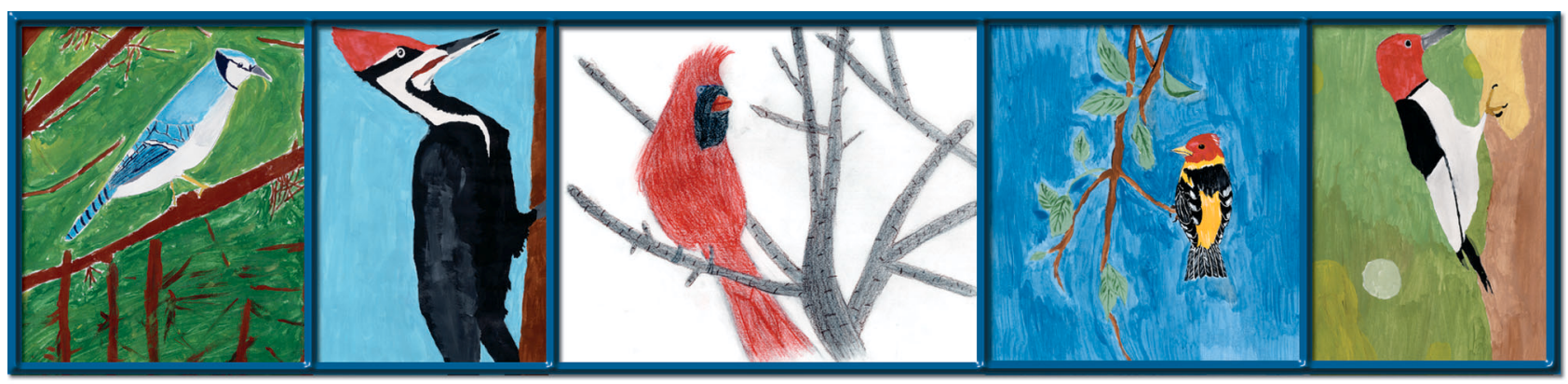

Student art, right to left: John Bamburg, Blake Violette, Brittany Scott, Christina Baloga, and Jordan Chester

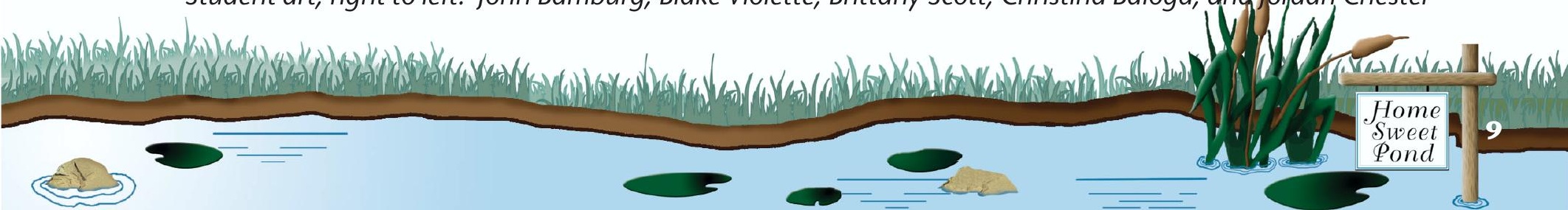


The following table identifies a few of the many environmental laws that regulate activities on the Oak Ridge Reservation during 2002.

\section{Clean Water Act}

\section{Safe Drinking Water Act}

Endangered Species Act

Comprehensive Environmental Response, Compensation, and Liability Act

\section{Resource Conservation and Recovery Act}

Federal Facilities Compliance Act

Federal Insecticide, Fungicide, and Rodenticide Act

\section{National Environmental Policy Act}

National Historic

Preservation Act

Toxic Substances Control Act

\section{INFORMATION}

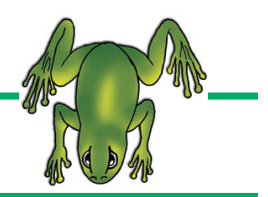

This act protects and improves air quality in the United States. It establishes a dose limit of 10 millirem per year for air emissions. The total 2002 dose from Oak Ridge Reservation activities was 0.3 millirem.

This law was passed in response to growing public awareness and concern for controlling water pollution. The Act established the basic structure for regulating discharges of pollutants into the waters of the United States. The compliance rate for all three sites was greater than $99.9 \%$.

This statute establishes drinking water regulations.

This act dictates that plan and animal species be considered when projects could alter their habitats.

Congress passed this law (also known as "Superfund") in response to a growing national concern about the release of hazardous substances from abandoned waste sites. Compliance with this act ensures that the environmental impacts of past and present activities on the Reservation are investigated and measures are taken to protect the public and the environment. There were no reportable releases from the reservation under this act during 2002.

This act gave Environemtnal Protection Agency the authority to control hazardous waste from the "cradle-to-grave." This includes the generation, transportation, treatment, storage, and disposal of hazardous waste.

This act was passed to bring federal facilities into compliance with the Resource Conservation and Recovery Act.

The primary focus of this act was to provide federal control of pesticide distribution, sale, and use. No restricted-use pesticides are used at any of the three sites.

This act requires the evaluation of environmental impacts of proposed projects and the examination of alternatives.

This act provides for the preservation of historic properties throughout the nation.

This law regulates the manufacture, use, and disposal of chemical substances.

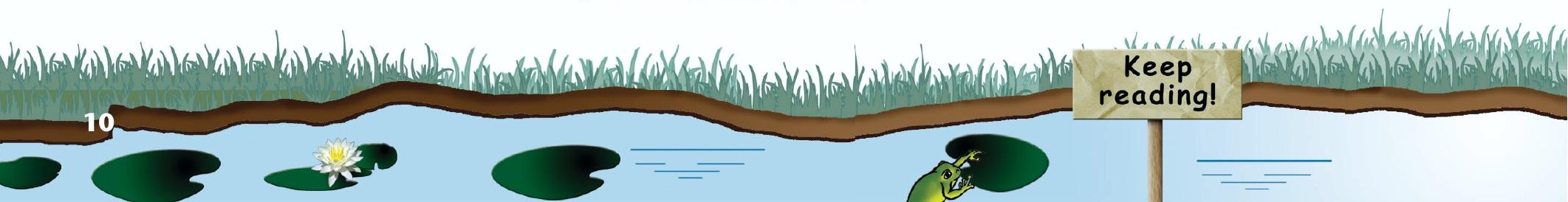




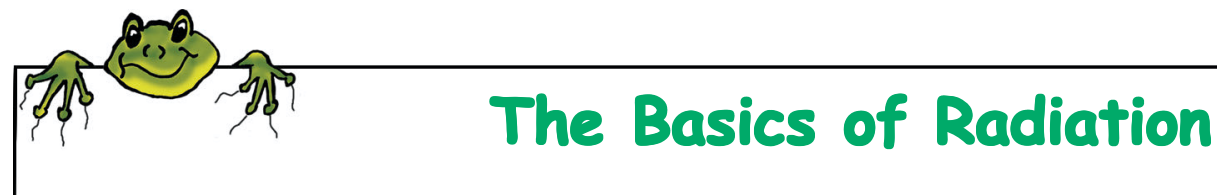

Though radiation may be hard to comprehend and even confusing, like all things it can be made easier to understand. We hope this section helps clear up some of the concerns or questions you may have about radiation and its effects.

\section{What is Radiation?}

Radiation is simply energy in the form of waves or particles moving through space. It is either natural or human-made. Sunshine and heat are some of the most familiar forms of natural radiation while $\mathrm{x}$-rays and gas heat are familiar forms of humanmade radiation. We all benefit from a multitude of products and services made possible by the careful use of radiation.

All matter is composed of chemical elements such as carbon, oxygen, or hydrogen. An atom is the smallest particle of an element that can exist either alone or in combination. All atoms are composed of three basic particles: protons, neutrons, and electrons. The proton carries a positive charge of electricity, the electron carries a negative charge, and the neutron has no charge. Protons and

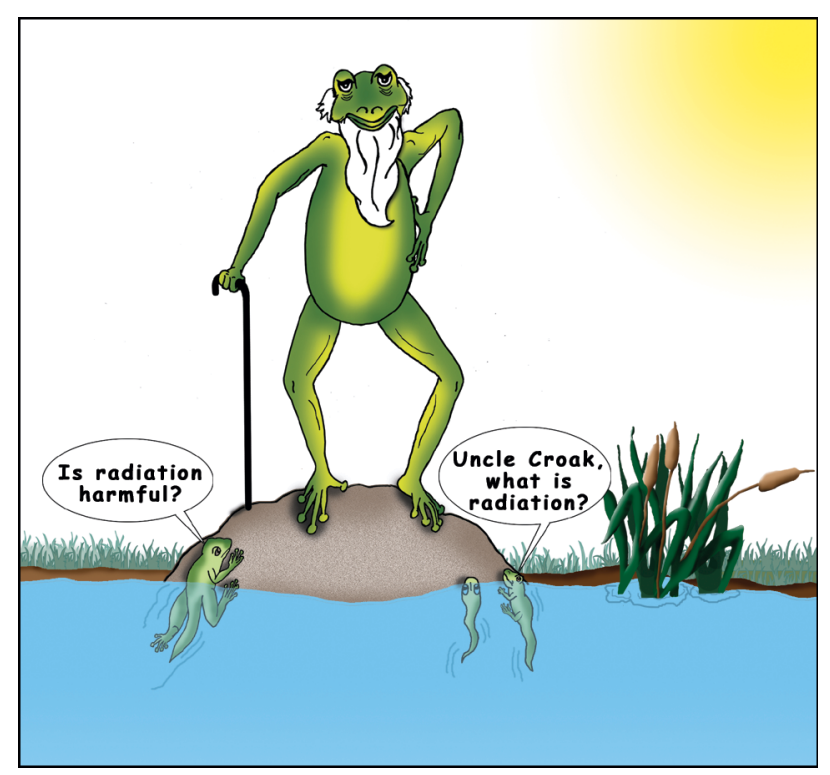
neutrons form the nucleus of the atom while electrons orbit around the nucleus. In most atoms, each positively-charged proton in the nucleus cancels out a negatively-charged electron, and the atom is electrically neutral or stable. Some atoms, however, have unstable nuclei due to an imbalance in the ration of neutrons to protons, and are characterized as being radioactive. To reach a stable state, a radioactive atom (radionuclide) releases energy from its nucleus and forms an atom of a different element. The kinds of radiation are electromagnetic (like light) and particulate. Gamma radiation and $\mathrm{x}$ rays are examples of electromagnetic radiation. Beta and alpha radiation are examples of particulate radiation.

Alpha particles are composed of two protons and two neutrons. Alpha particles do not travel very far from their radioactive source. They cannot pass through a piece of paper, clothes, or even the layer of dead cells which normally protects the skin. Because alpha particles cannot penetrate human skin they are not considered
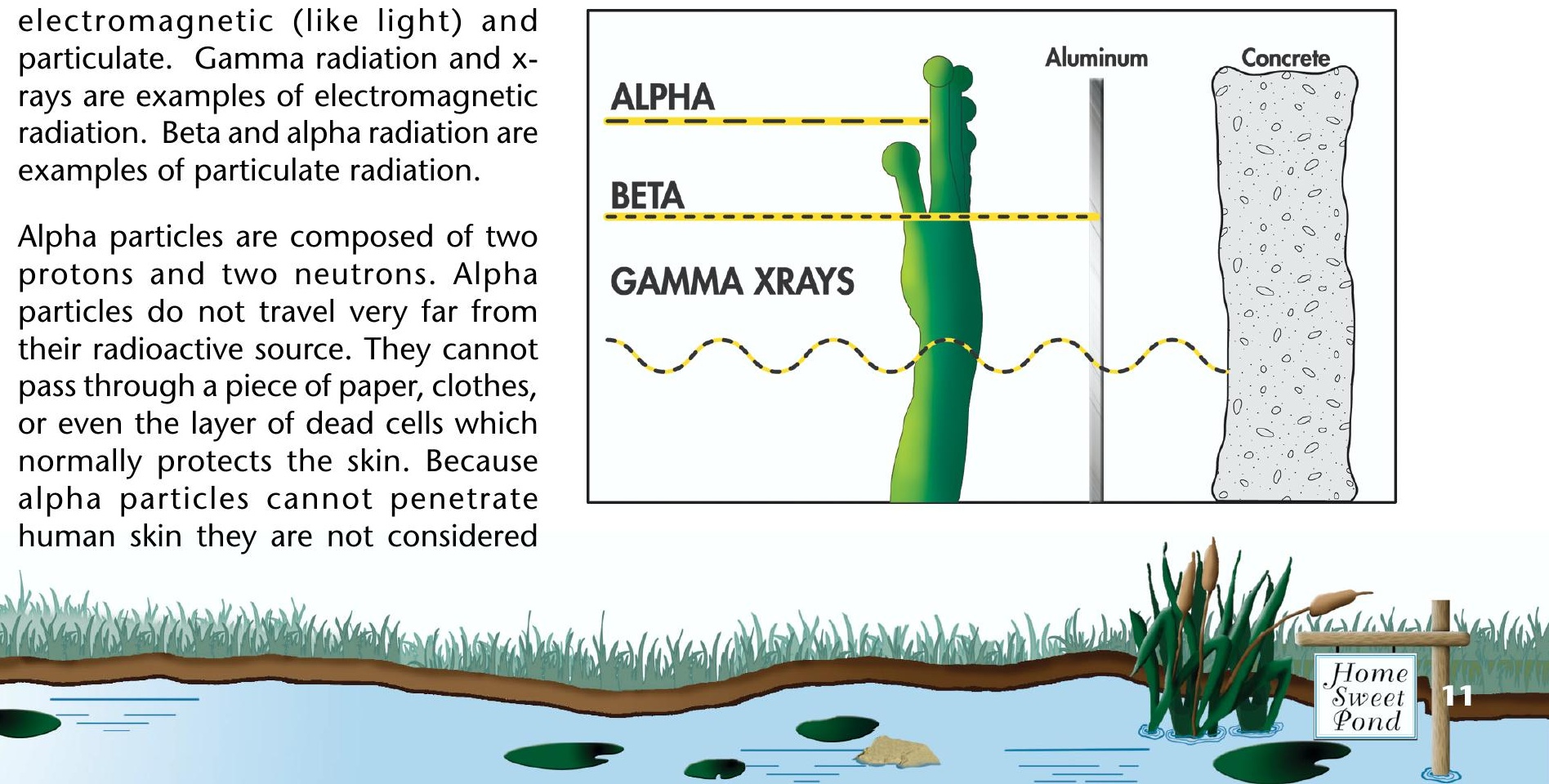
Beta particles cannot travel very far from their radioactive source, and they are only moderately penetrating. For example, they can travel only about one half an inch in human tissue, and they may travel a few yards in air. They are not capable of penetrating something as thin as a book or a pad of paper, and clothing can be effective in preventing skin exposure to beta particles. However, beta-emitting contaminants that do reach the skin and are allowed to remain there for a prolonged period of time may cause skin injury.

Gamma radiation originates from the nucleus of an atom, is able to travel many meters in air, and readily penetrates human skin. In fact, it is often referred to as "penetrating radiation." Radioactive

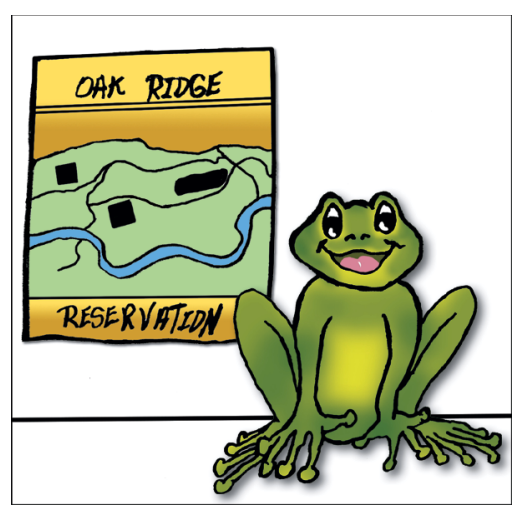
materials that emit gamma radiation and X-rays constitute both an external and internal hazard to humans. Dense materials such as lead or concrete are needed for shielding from gamma radiation. Clothing provides little shielding from penetrating radiation but will prevent contamination of the skin by radioactive materials.

In our daily lives, we are exposed to various types of naturally occurring radiation from cosmic rays, from radioactive substances in the earth, and from naturally occurring radiation in our bodies. We are also exposed to man-made sources of radiation such as x-rays, building masonry, gas stoves, computer monitors and televisions. Radiation has many applications in agriculture, medicine, industry and research, and greatly improves the day to day quality of our lives. On the average, naturally occurring sources contribute about four to five times as much to an individual's exposure as human-made sources. Average radiation exposure in the United States from natural and human-made sources is about 360 millirem per year. Levels of natural radiation can vary greatly. People living in granite areas receive more terrestrial radiation than others, while people living or working at high altitudes receive more cosmic radiation. A lot of our natural exposure is due to radon, a gas which seeps from the earth's crust and is present in the air we breathe. Our bodies also contain natural radionuclides such as Potassium-40 which contributes an average dose of approximately 40 millirem per year.

\section{What is dose?}

Dose is a general term denoting the quantity of radiation or energy absorbed in a specific mass. It is a measure of the effect of exposure and the potential for damage rather than just the amount of the exposure. Whether natural or human-made a specific dose of radiation has the same effect on people. Radiation dose is usually expressed in a unit called rem. There are 1000 millirem in a rem. In the United States, the average person receives 360 millirem of radiation dose per year. Dose is measured by considering the potential types of exposure, including direct radiation and the ingestion of food and water containing radioactive materials. If an individual received a dose of 100,000-200,000 millirem they would show signs of radiation sickness, but would most likely recover completely. A dose of 800,000 millirem or more would probably be fatal without medical treatment. It is highly unlikely for anyone to receive this amount of radiation. People who work with radiation are allowed to receive up to 5,000 per year. In 2002 the highest dose to a worker at ORNL was 700 millirem, the highest dose to a Y-12 worker was 535 millirem, and the highest worker dose at ETTP was

\section{Are we at risk?}

Are we at risk living near the Oak Ridge Reservation? The annual radiation dose to individuals living near the Department of Energy's Oak Ridge facilities is between .01-12 millirem per year. This is less than is received from concrete block in schools, stores, buildings, or homes made of concrete. Smoking cigarettes can result in exposures of 15-20 millirem per year. Radon which is natural in the earth can

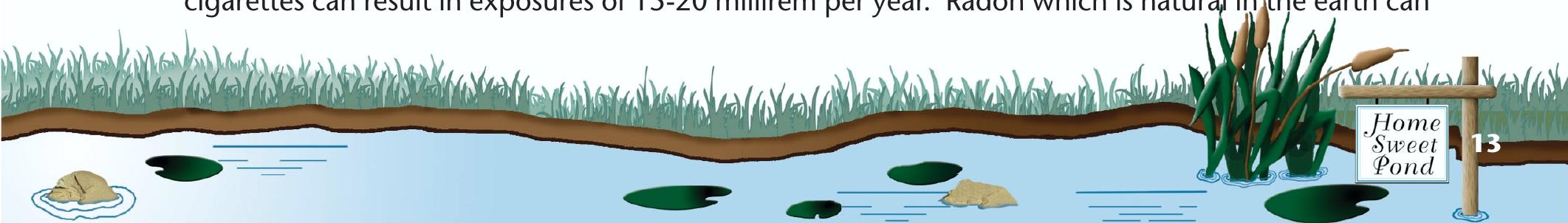




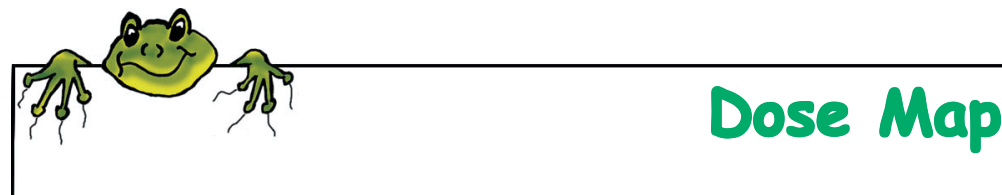

Everyone is exposed to radiation through normal daily activities. A typical person in the United States receives approximately 300 millirem per year from all natural sources of radiation, such as cosmic rays from outer space; radon from the ground; and natural radioactive elements found in soil, water and food. In addition, about 60 millirem per year comes from man-made sources, such as medical and dental exams, air travel, and consumer products.

Monitoring of air, water, and wildlife on and near the Reservation provides data that are used to confirm that doses from radionuclides released from the Department of Energy activities are low and are in compliance with all laws.

The radiation dose (a measurement of the amount of energy from radiation) varies depending on location. If you live in the vicinity of the Oak Ridge Reservation, eat lots of fish and wildlife harvested locally, drink gallons of contaminated water, and get all the highest exposures possible, you could receive up to 10 millirem per year, about $3 \%$ of natural background.

\section{Radiation Doses on or Near the Oak Ridge Reservation}
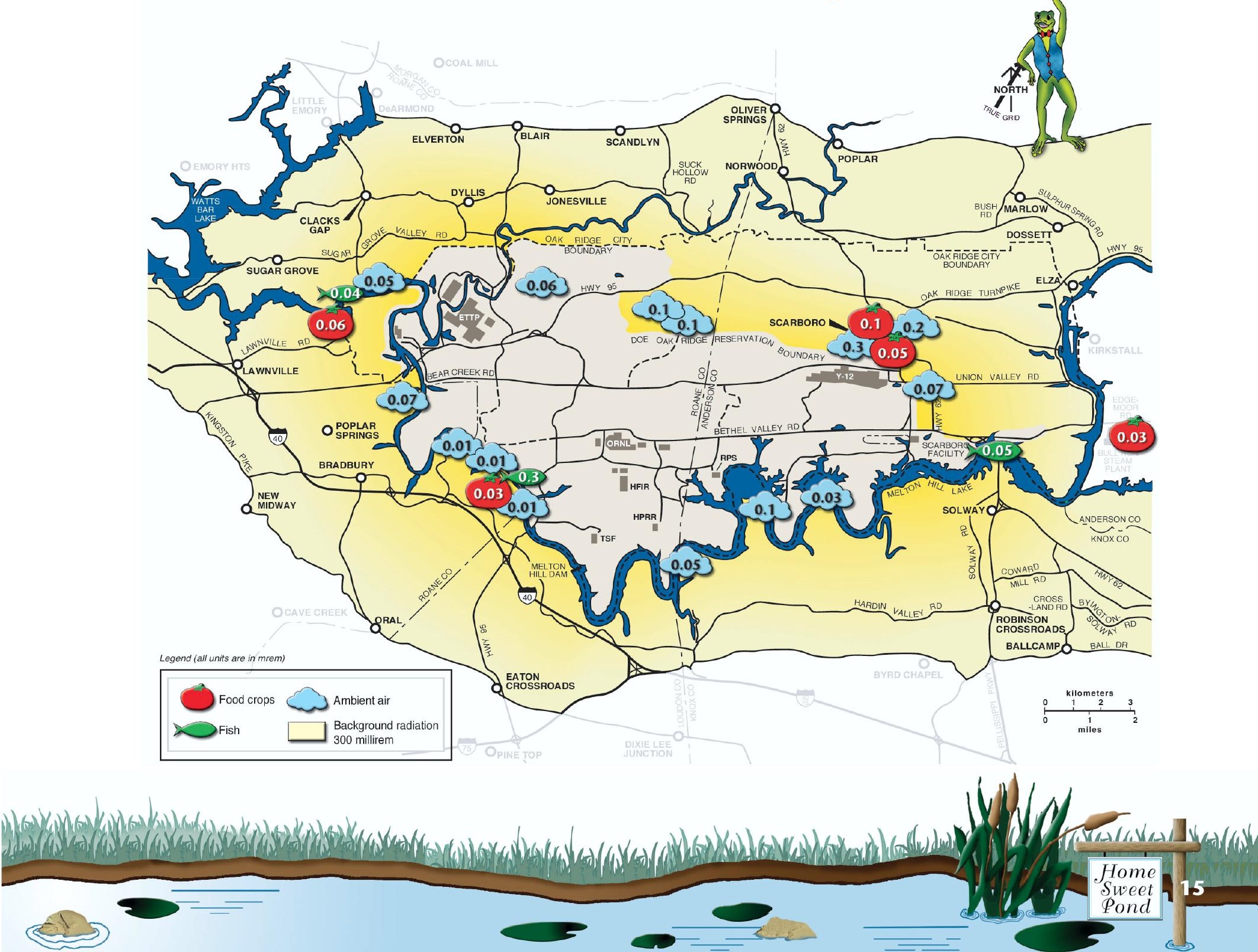
the Oak Ridge National Laboratory and at the East Tennessee Technology Park have not detected groundwater contamination migrating off Department of Energy Property. At the Y-12 Security Complex chlorinated volatile organic compounds have migrated off the Oak Ridge Reservation east of the plant into Union Valley at depths between 200-500 feet. Remediation is being conducted to mitigate plume migration. Meanwhile, there are no users of the groundwater, and restrictions have been established to prevent future use.

\section{Canada Geese}

Open hunts for Canada geese are held in counties near the Oak Ridge Reservation each year. Therefore geese from on and around the reservation are rounded up each summer for radiation screenings. The 2002 roundup was held June 20 and 21, and 105 geese were screened for radiological activity. None of these geese were sacrificed as a result of radiation levels exceeding release limits.

\section{Eastern Wild Turkeys}

Wild turkey hunts were held on the Oak Ridge Reservation on April 6 \& 7, 2002 and on April 13-14, 2003. Hunting was open for both shotguns and archery. Thirty-eight turkeys were killed during the 2002 hunts and none were confiscated because of radiation levels. Turkey hunts have been held on the reservation each year since 1997 and a total of 344 turkeys have been harvested. Of these, only two have been kept because of potential radiological contamination.

\section{Fish}

Fish from three locations on the Clinch River are collected annually and edible portions are analyzed for contaminants originating from the Oak Ridge Reservation. Sunfish and catfish are collected from each location. Consumption of fish caught around the Oak Ridge facilities is limited due to advisories for polychlorinated biphenyls issued by the Tennessee Department of Environment and Conservation. Polychlorinated biphenyls are found all over the United States, and the local advisories are for the entire reservoir and not just the areas around the Oak Ridge Reservation. The maximum radiation dose from eating local fish was calculated to be approximately 2.4 millirem. Two millirem of this dose is due to the presence of naturally occurring Potassium 40. Therefore, only 0.4 millirem could potentially be due to Oak Ridge Reservation activities.

\section{Vegetables}

Tomatoes, lettuce, and turnips were bought from farmers near the reservation. Locations were chosen based on availability and on their likelihood of being affected by routine releases from the Oak Ridge facilities. All radionuclides found in the food crops are found in the natural environment. The highest dose to a gardener in the vicinity of the Oak Ridge Reservation could have been about 0.1 millirem from consuming all three types of these vegetables.

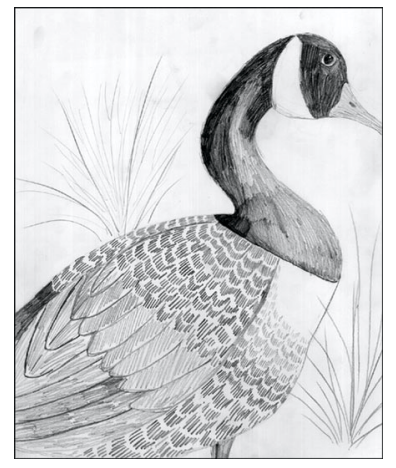

Student art, Victoria Drew

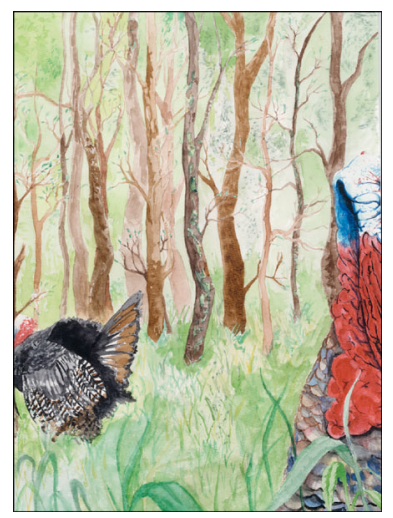

Student art, Austin Hale

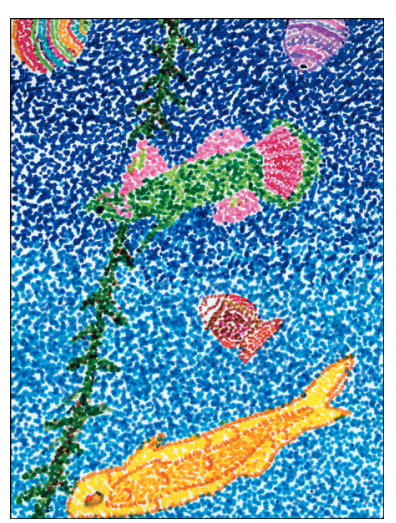

Student art,

Chelsea Brooks

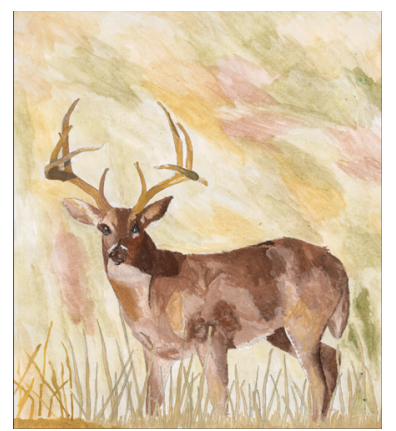

Student art, Jarrett Benson

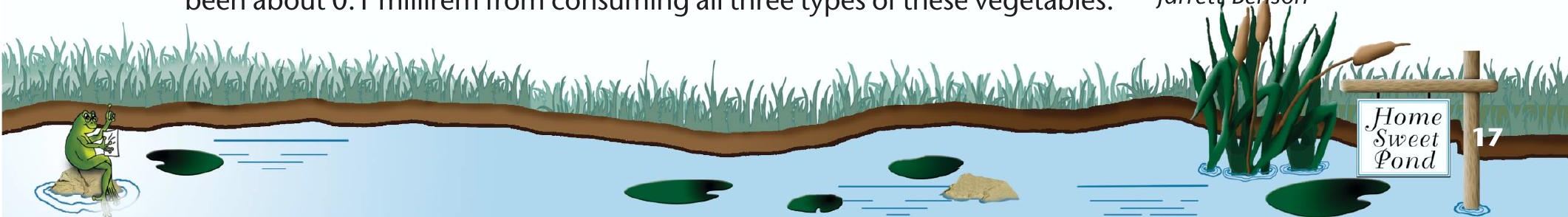




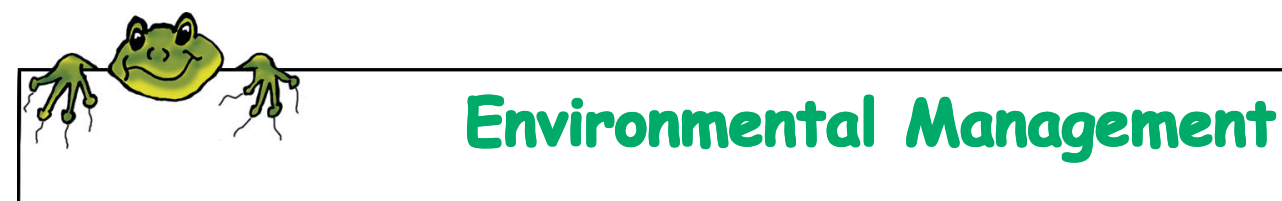

\begin{abstract}
This section will show you how you can be a part of decision making on the Oak Ridge Reservation and how you can stay informed on activities carried out by the Department of Energy?
\end{abstract}

\title{
Public Involvement
}

The Department of Energy Oak Ridge Operations Office encourages stakeholders to participate in decisions and exchange information regarding remediation of contaminated areas on the Oak Ridge Reservation. Stakeholders include individual groups, host communities, and other entities in the public and private sectors that are interested in or affected by Department of Energy activities and decisions. The following sources of information are available to stakeholders and the general public:

- The Oak Ridge Site Specific Advisory Board, a federally appointed citizen panel, provides advice and recommendations to DOE on environment activities (http://www.oro.doe.gov/em/ssab).

- The Oak Ridge Reservation Health Affects Subcommittee, funded by the Department of Energy and administered through the Agency for Toxic Substances and Disease Registry, performs public health assessments for contaminants by looking at present and historical releases from the Oak Ridge Reservation and their potential impact on the health of nearby residents. Subcommittee meetings and technical work group meetings are open to the public.

- The Tennessee Department of Environment and Conservation, Department of Energy Oversight Office provides independent State oversight of the Department of Energy's Oak Ridge activities; (http://www.state.tn.us/environment).

- Local Oversight Committee provides public oversight of the environmental management activities of the Department of Energy, Oak Ridge Operations Office (http://www.localoversight.org).

- The Department of Energy Information Center (phone: 865-241-4582) provides newsletters, reports, and tapes and transcripts of public meetings and DOE activities (http:// www.oro.doe.gov/foia/doe_public_reading_room.htm).

- The City of Oak Ridge Environmental Quality Advisory Board, appointed by the Oak Ridge City Council, provides counsel to the city government on environmental matters (http://orserv01.ci.oak-ridge.tn.us/ComDev-thml/EQAB.htm).

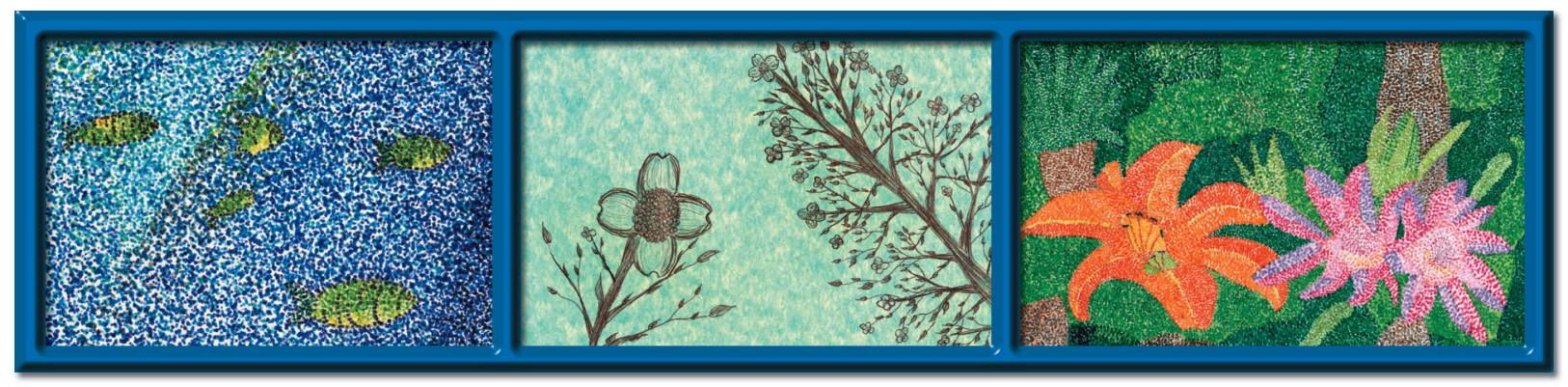

Student art from left to right, Kamillia Halloun, Tyler Blazer, and Kayce Baker

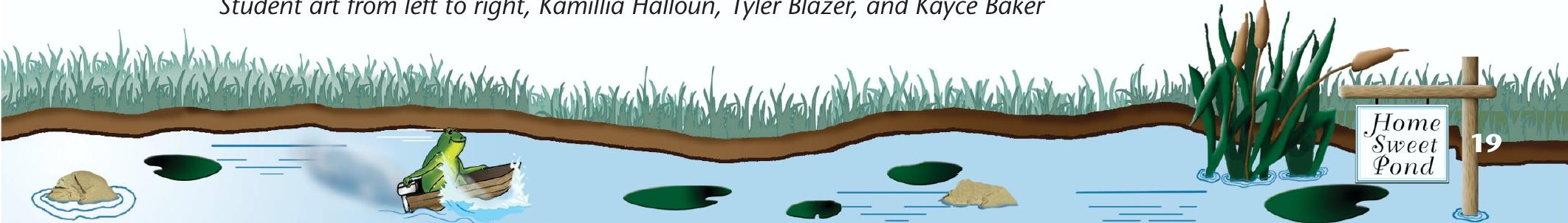




\section{Oak Ridge Reservation Annual Site Environmental Report Summary 2002}

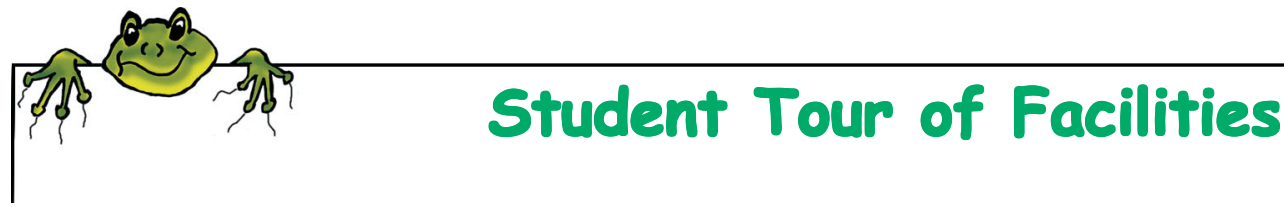

Summarizing the approximately 350-page Annual Site Environmental Report could have been an overwhelming task for a group of high school students, many of whom have had little or no education in radiation, environmental compliance, chemistry, graphics, or technical writing. In order to make this undertaking less daunting, Department of Energy and UTBattelle project managers worked with the students on a routine basis for the entire semester, and brought scientists from each of the sites, dose assessment personnel, and graphic artist staff to the classroom for special instruction. The student authors also visited the Reservation in order to better understand the history, geography, and activities associated with the Department of Energy's facilities in Oak Ridge. Environmental sampling technicians conducted tours of air and water sampling stations and demonstrated the instrumentation used to collect environmental samples. Representatives from each of the three major sites provided historical information and showed the class the major areas of interest at each facility. The students then returned to the classroom to produce this environmental summary which describes the Oak Ridge Reservation's environmental monitoring programs and compliance status in a brief and technically accurate document.

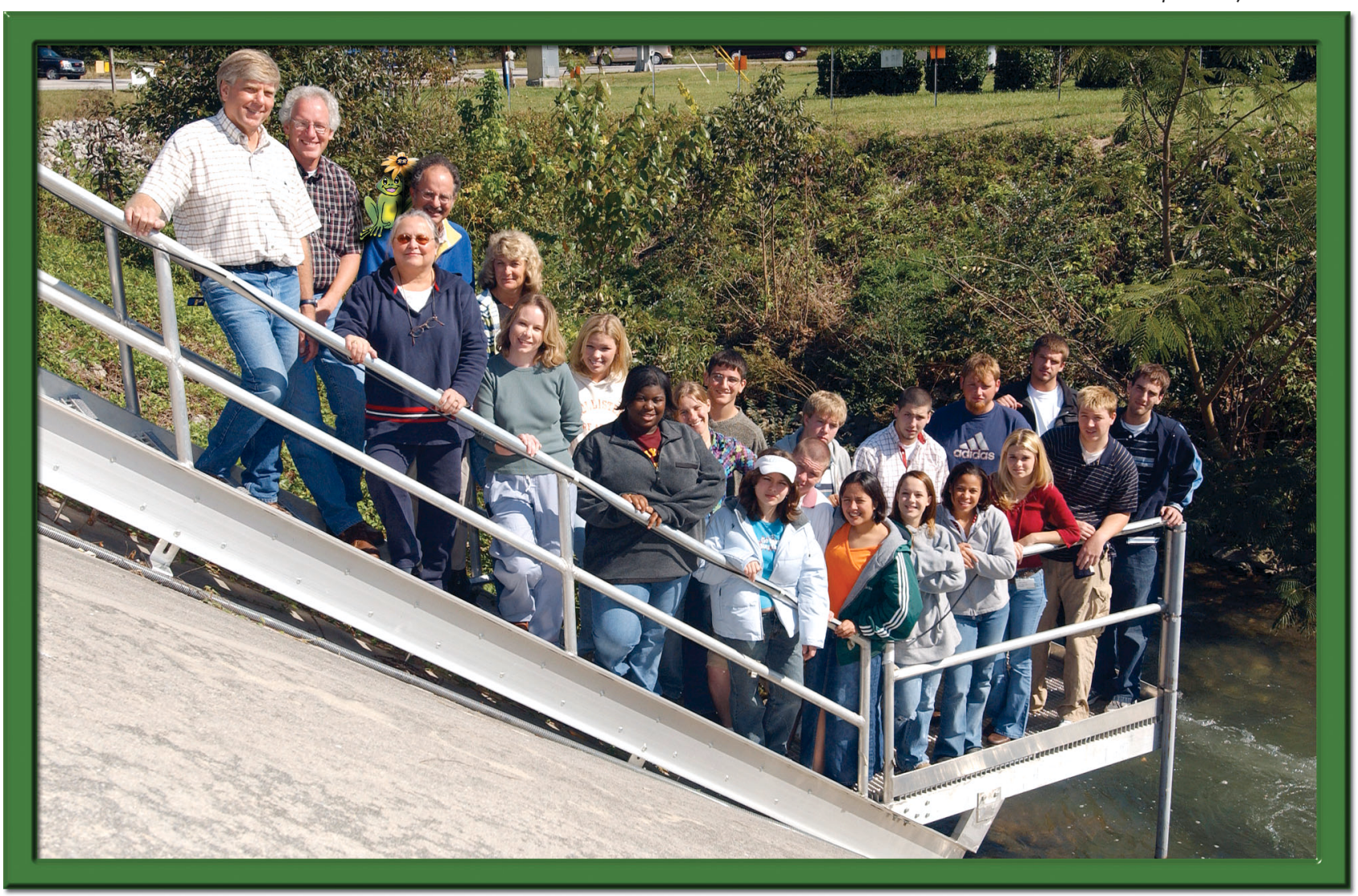

Front Row left to right: Steve Field, Jennifer Webster, Julie Hardie, Michelle Washington, Dana Davis, Rosario Belmares, Tiffany Turner, Nicole Kimber, Justina Clairborne, Chris Noe, and Jason Sherrod

Back row left to right: Don Bohrman, Timothy Joseph, Joan Hughes, Samantha Wilson, Brittany Day, Wil Peyrot, Tim Johnson, Wes Forman, Logan Lunsford, Chris Price, and Josh Powell

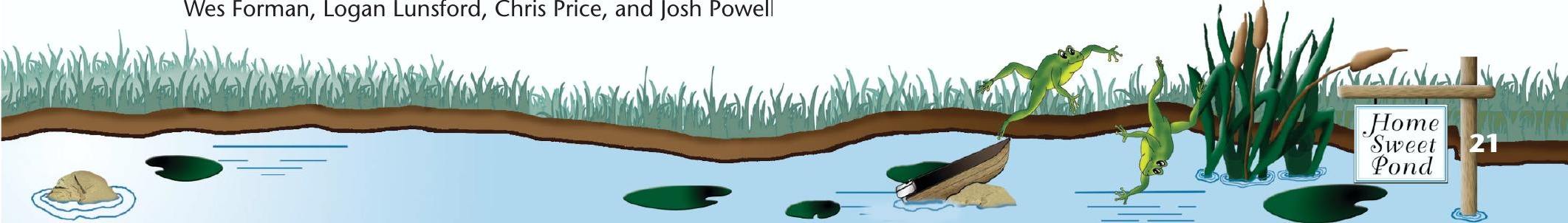




\section{Oak Ridge Reservation Annual Site Environmental Report Summary 2002}

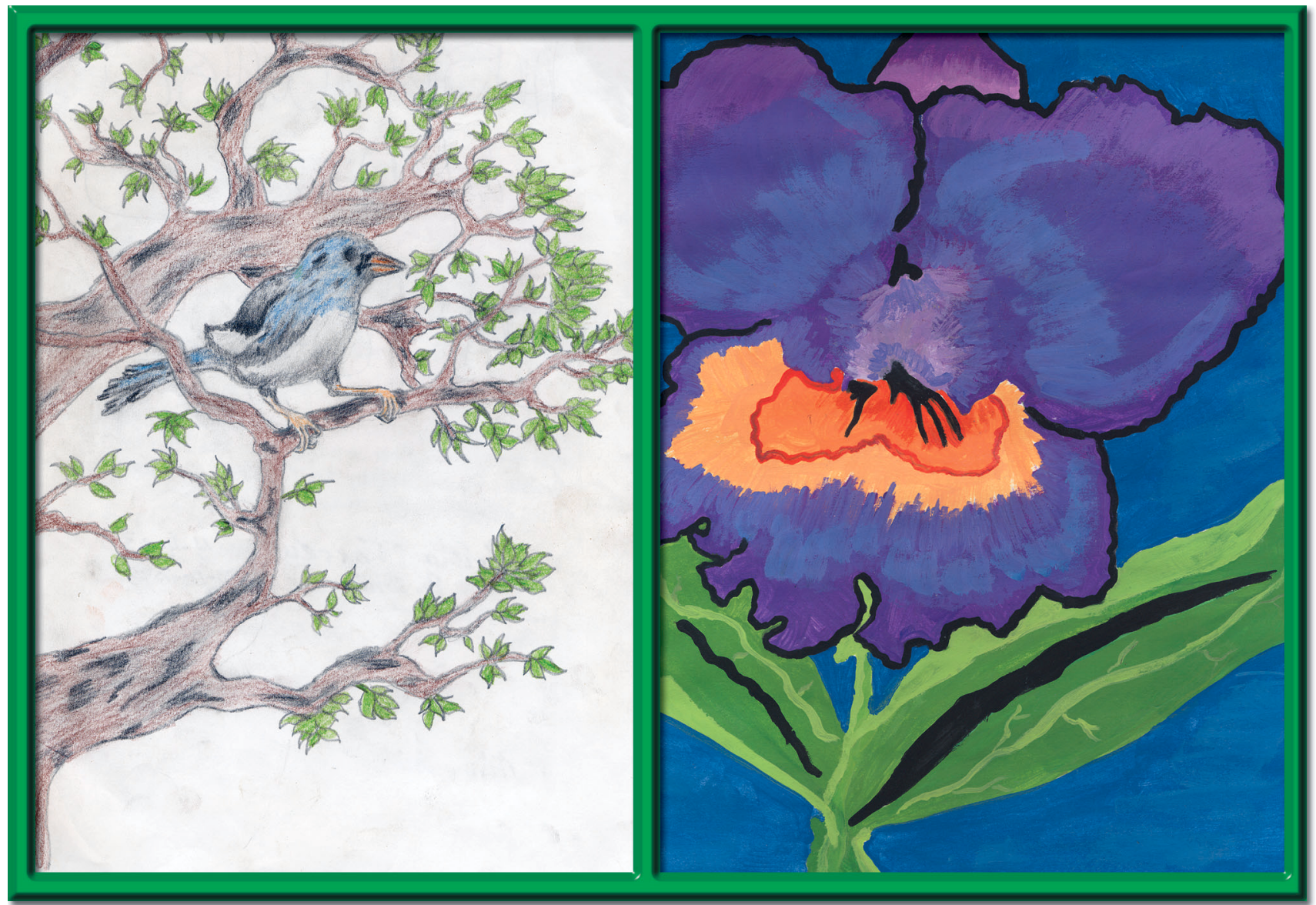

Student art from left, Krista Torrey and Sarah Price

\section{Disclaimer}

This report was prepared as an account of work sponsored by an agency of the United States Government. Neither the United States nor any agency thereof, nor any of their employees, makes any warranty, express or implied, or assumes any legal liability or responsibility for the accuracy, completeness, or usefulness of any information, apparatus, product, or process disclosed, or represents that its use would not infringe privately owned rights. Reference herein to any specific commercial product, process, or service by trade name, trademark, manufacturer, or otherwise, does not necessarily constitute or imply its endorsement, recommendation, or favoring by the United States Government or any agency thereof. The views and opinions of authors expressed herein do not necessarily state or reflect those of the United States Government or any agency thereof.

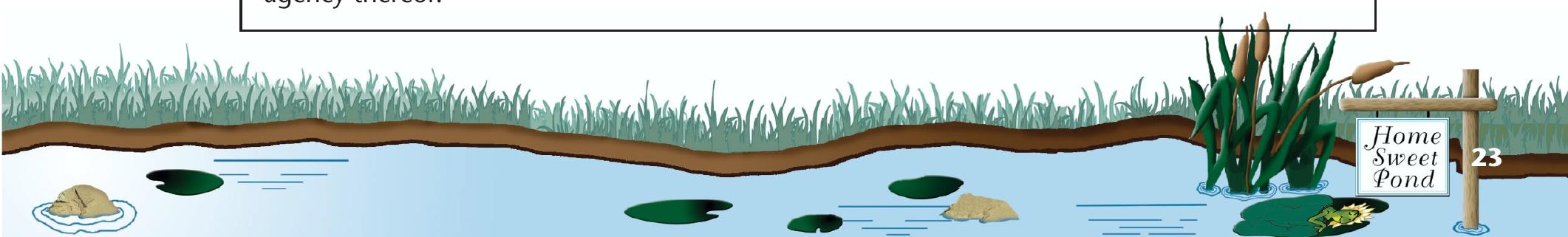




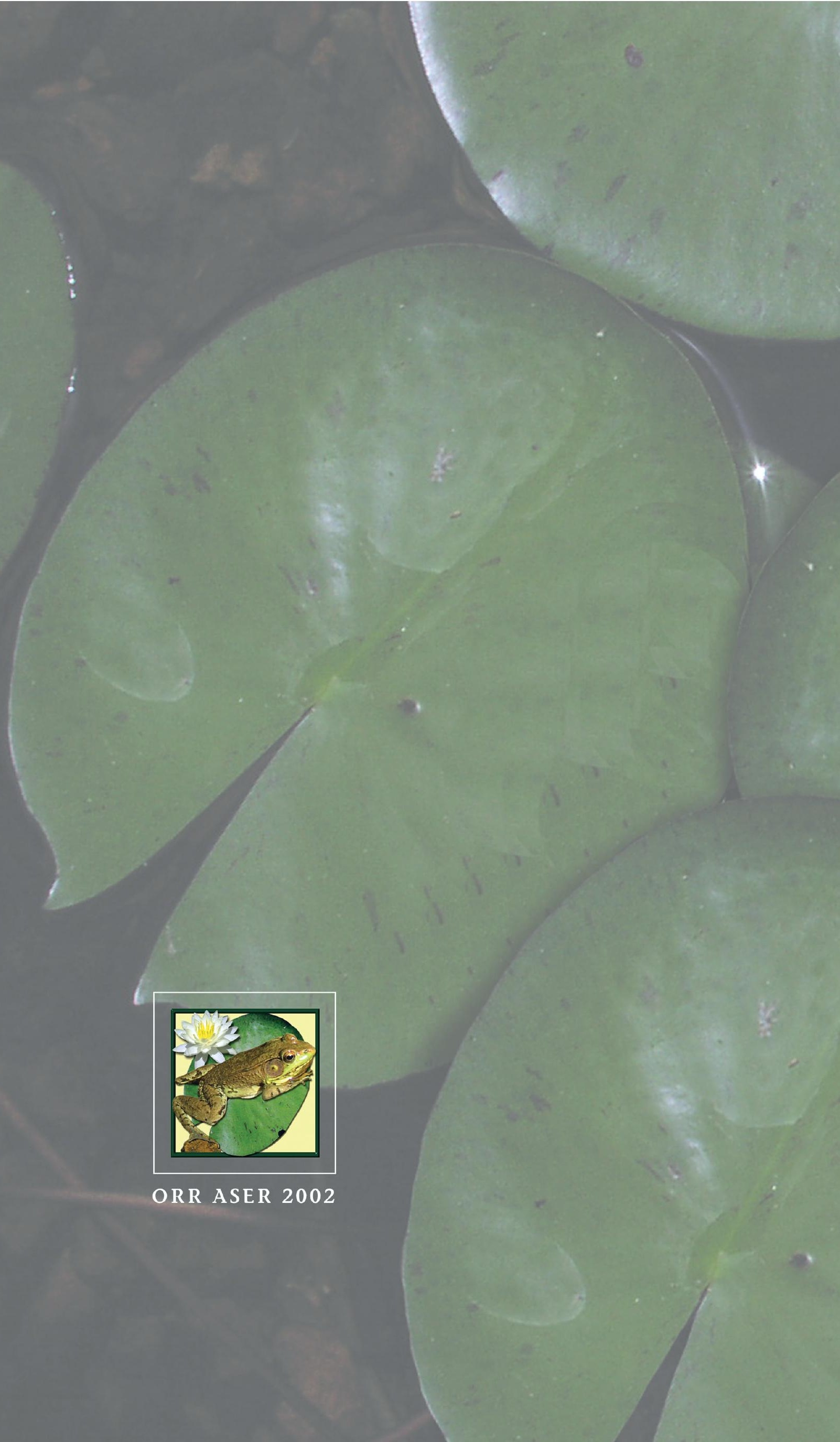

